\title{
SALTO QUALITATIVO
}

Vinícius Bandera ${ }^{1}$

A distância era impressionante. O impacto com a água fria faria qualquer um afundar por um tempo que poderia ser fatal. Era preciso muito fôlego para quem escapasse de morrer do choque com a lâmina d'água. Os corpos apareciam boiando, somente o de Mulin de nada se soube. Daí a inferência, lendária ou não, dele ter escapado. Dustin já não aguentava mais as investidas de Mulin em desejar convencê-lo a saltar. Dustin chegara à conclusão de que em sua idade saltar era-lhe algo irreversivelmente afogado nas veleidades de outrora. Conformava-se em olhar o horizonte sem desejá-lo. Ver os pássaros voando sem querer imitá-los. Mulin falava-lhe de cassinos, mulheres, ruas cheias de gente, luzes da noite... Dustin ouvia-o sem poder mais imaginar a imaginação de seu amigo. Perguntava-se como ele podia falar de coisas tão distantes no tempo e no espaço, como ainda podia lembrar-se delas. Mulin não se dava conta, pensava Dustin sem nada dizer-lhe, de que não era mais o jovem que havia muitos anos ali chegara e quebrava pedras do nascer ao pôr do sol. Naquela época ele não insistia em tentar. Não acreditava que fosse possível; disse isso várias vezes para Dustin, quando este apresentava a questão como a única alternativa de liberdade, tendo a esperança de o tempo poder trazer uma solução que só ele parece ser capaz de fazê-lo. O tempo passou levando a esperança, restando o desespero em uns e a conformação em outros. Mulin estava entre os primeiros e Dustin entre os segundos, embora fosse também um desesperado. Ajudava Mulin a lançar ao mar sacos cheios de pedras. Mulin calculava que cada saco pudesse ter uns setenta quilos, justamente o peso corporal que ele supunha ter. Os dois procuravam calcular o impacto de cada saco contra a água e sua velocidade a descer ao fundo do mar. Não havia nenhuma precisão nos cálculos, pois não possuíam nenhum equipamento a poder garantir uma aferição confiável. No entanto, chegaram à ilação de que o mais seguro era saltar no momento imediato ao qual uma onda arrebentasse contra a rocha, pois isso tornaria a lâmina d'água menos tesa, portanto mais flexível para receber o impacto de um homem a se lançar dos cinquenta, ou pouco mais, metros de altura. Esse homem deveria ser Mulin, pelo menos era para

\footnotetext{
${ }^{1}$ Pós-doutor em História (FFLCH/USP), Doutor em Sociologia (UFRJ) e Mestre em Ciência Política (UNICAMP)
} 
isso que ele estava treinando através dos sacos. Antes dele foram muitos a deixarem de ser tão logo seus corpos encontraram a água. Envergado pelo tempo, Dustin se dedicava a cuidar de sua horta. Um dia, Mulin, vendo-o capinar, perguntou-lhe por que não plantava algodão. O amigo tirou o boné, colocou a mão para tapar os olhos contra o sol e o fitou sem entender a pergunta. Mulin tomou-o pelo braço e o levou até à beira do penhasco, de onde começou a explicar seu novo plano. Pretendia, com ramas e ramas de algodão trançado, fazer uma corda de mais de cinquenta metros a poder levá-lo à superfície do mar sem necessidade do salto, provavelmente mortal. Dustin ouviu-o por uns vinte minutos, sem interrompê-lo, com a indiferença de como fitava o horizonte em seus fins de tarde. Quando Mulin parou de falar, certo de que o convencera e a si mesmo, Dustin lhe perguntou como eles conseguiriam plantar algodão naquele lugar esquecido por Deus. Como obteriam as sementes? Mulin tentou atirar-se ao mar e mesmo ao rochedo, Dustin ainda teve tempo de segurá-lo pelas pernas. Os dois a gritar desesperadamente. Mulin pela inutilidade de seu novo plano de fuga, Dustin a gritar para que o amigo se acalmasse. Não tardaram em aparecer colegas a os retirar daquele lugar a os colocar em perigo de vida. Logo a noite desceu. No dia seguinte, Mulin procurou Dustin em busca dele o ajudar a carregar um saco cheio de pedras. Tal atividade estava afetando a coluna de Dustin, mas ele não queria queixar-se ao amigo. $\mathrm{O}$ seu interesse maior era ajudá-lo a mitigar o seu desespero. Mulin dizia-lhe, enquanto carregavam o saco, que deviam calcular o tempo exato entre a formação de uma onda e o momento de ela chocar-se contra a rocha; assim, quando a onda se formasse, o saco a encontraria justamente no instante imediato ao choque dela contra a rocha. Dessa maneira, a penetração na lâmina d'água seria menos impactante. Segundo Mulin, todos os que tentaram a fuga morreram não no afogamento, mas antes disso, no impacto com a água lisa, isto é, a água antes da onda bater na rocha e voltar turbulenta. Em cinco anos de estudo desse tema, após várias comprovações empíricas, Mulin tornou-se um especialista em saltar para a liberdade; pelo menos supunha sê-lo, para o indefectível descrédito silencioso de Dustin. A ninguém Mulin conseguia convencer a segui-lo; isso o entristecia sobremaneira e mais e mais o desesperava. Quantas vezes não pensou em jogar-se do penhasco abaixo, como fizera aos seus muitos sacos sem vida. Dustin olhava o amigo mirar o horizonte sem a sua indiferença contumaz, mas com um incontido desassossego diante de sua descrença quanto a qualquer possibilidade de fuga. Mulin, pelo contrário, estava ainda mais esperançoso e lembrou que no dia do salto deveria antes jogar algo leve ao mar, para certificar-se se o vento estaria fraco. Com 
vento forte o seu corpo poderia desviar-se da trajetória, fazendo-o perder alguns segundos em atingir a água no momento alto de sua flexibilidade, devido à turbulência provocada por uma das ondas. Outro perigo ainda maior seria se o vento o levasse a explodir contra uma das paredes do rochedo, como já acontecera a vários dos que tentaram. Esse quadro de variantes escapava ao seu controle, tirava-lhe noites e noites de sono, quando não o fazia acordar aos gritos, imaginando-se despedaçado na pedra dura ou na água inflexível. Quase nunca colocara como hipótese morrer por afogamento. Acreditava poder aguentar descer uns trinta metros, durante uns trinta a quarenta segundos, depois subi-los em um minuto. Um minuto e quarenta segundos, dois minutos no máximo, tempo necessário para imergir e emergir são e salvo, malgrado o corpo dolorido e o cansaço do esforço pulmonar. E depois? Não tinha ideia sobre o que havia para além do horizonte. Vieram para ali de olhos vendados, acorrentados ao fundo da embarcação. Era uma lancha de pouca potência. Acreditava terem gasto em torno de trinta minutos para completar a travessia. Mas isso havia cerca de quarenta anos. Enquanto fazia os testes com os sacos, Mulin testava também construir uma espécie de flutuante de madeira para servir de embarcação a amparar o seu corpo no mar. $\mathrm{O}$ grande problema era fazer com que os tempos das quedas de seu corpo e desse flutuante não se dessem a grande distância um do outro, caso contrário ele deveria nadar a mar aberto até a possibilidade de encontrar terra firme. Missão praticamente impossível sem o flutuante a lhe servir de arrimo. Em uma de suas muitas noites insones, teceu a ideia de se lançar ao mar com o flutuante amarrado a si, através de uma corda, ou algo semelhante, de uns cinco metros. No dia em que Mulin se jogou, formou-se, como de praxe nesses casos, uma roda de companheiros de infortúnio a desejar-lhe boa sorte. Ele fez tudo de acordo com o planejamento urdido ao longo de meses. Os homens viram quando o seu corpo foi tragado por uma onda a lhe amortecer o impacto. Outra onda, outra, outra... As ondas se sucediam, como vinha acontecendo desde anos incomensuráveis, talvez anos a se perderem na eternidade. O corpo de Mulin não apareceu boiando, como muitos outros. Não se chocou contra as pedras, como vários. Os homens gritavam efusivamente. Mulin conseguiu! Mulin conseguiu! Mulin conseguiu! Era o que gritavam numa explosão de felicidade, como se cada um ali alcançasse para si próprio a liberdade. Dustin chorava convulsivamente. Não tardou a chegar a noite e um vento forte a deixar o mar agitado. No dia seguinte, os homens se perguntavam por que o corpo fugira à visão de todos, um forte indício sobre a possibilidade de ele ter sobrevivido ao choque à água e à imersão e emersão. Conta a 
lenda que Mulin foi o primeiro a sair com vida da única tentativa de fuga possível do inferno a habitar aquele lugar. A história verdadeira foi tragada pela água profunda e assassina de tanta gente que nela buscara a libertação. 